\title{
Osteogenezis İmperfekta Tanılı Bireylerde Teriparatid Tedavisinin Retrospektif Olarak Değerlendirilmesi
}

\author{
Yasemin AYDOĞAN ÜNSAL ${ }^{1}$, Özen ÖZ GÜL ${ }^{1}$, Soner CANDER ${ }^{1}$, Canan ERSOY ${ }^{1}$, \\ Ensar AYDEMIR ${ }^{1}$, Oktay ÜNSAL ${ }^{2}$, Erdinç ERTÜRK ${ }^{1}$ \\ 1 Bursa Uludağ Üniversitesi Tıp Fakültesi, Endokrinoloji ve Metabolizma Hastalıkları Bilim Dalı, Bursa. \\ 2 Ankara Gazi Üniversitesi Tıp Fakültesi, Onkoloji Bilim Dalı, Ankara.
}

\section{ÖZET}

Osteogenezis imperfekta (OI) düşük kemik mineral yoğunluğuna ve artmış kemik frajilitesine yol açan kalıtsal bir hastalıktır. Bu makalede kliniğimizde Oİ tanısı ile takipli, tedavilerinde teriparatid veya zolendronik asit (ZA) kullanılan hastaların retrospektif olarak klinik, laboratuvar parametreleri ve kemik mineral yoğunluklarını değerlendirmeyi amaçladık. Takiplerinde teriparatid ile ZA tedavisi alan toplam 9 hasta değerlendirildi. Teriparatid tedavisi alan hastaların tümünde klinik iyileşme sağlandı, tedavi süresince yeni fraktür saptanmadı. Olguların teriparatid tedavisi ile kemik mineral yoğunluklarının stabil seyrettiği görüldü. Teriparatid tedavisi sırasında olgularda yan etki gelişmedi. ZA tedavisi alan hastalarda kemik mineral yoğunlukları değerlendirildiğinde, lomber alanda kemik mineral yoğunluğunda artış izlendi. Olgularda yeni kırık oluşumu tespit edilmedi. ZA tedavisi uygulanan olgularda da tedavi sırasında yan etki gözlenmedi. ZA, erişkin OI olgularında tolere edilebilir yan etki profili ile efektif tedavi seçenekleri arasında yer almaktadır. Osteoanabolik bir ajan olan teriparatid de iyi tolere edilebilen, yan etkileri ve yapılan çalışmalarda gözlemlenen kemik mineral yoğunluğu üzerindeki olumlu etkileri de göz önüne alındığında Oİ vakalarında tercih edilebilir tedavi seçeneği olarak karşımıza çıkmaktadır.

Anahtar Kelimeler: Osteogenezis imperfekta. Teriparatid. Zolendronik asit. Kemik mineral yoğunluğu.

Retrospective Evaluation of Teriparatide Therapy in Individuals with Osteogenesis Imperfecta

\begin{abstract}
Osteogenesis imperfecta (OI) is an inherited disorder that causes low mineral density and bone fragility. In this article, we aimed to evaluate the clinical and laboratory parameters and bone mineral density of patients in whom teriparatide or zolendronic acid (ZA) was used in follow-up treatment with the diagnosis of OI in our clinic, retrospectively. During the follow-up, 9 patients who received teriparatide or ZA treatment were evaluated. Clinical improvement was achieved in all patients who received teriparatide treatment, no new fractures were detected during the treatment. It was observed that the bone mineral density of the patients treated with teriparatide treatment remained stable. No adverse events were observed during the treatment in the cases treated with teriparatide. When bone mineral density was evaluated in patients receiving ZA treatment, an increase in bone mineral density was observed in the lumbar area. New fractures were not detected in the cases. No adverse events were observed during the treatment in the cases treated with ZA. ZA is one of the effective treatment options with its tolerable adverse event profile in adult OI cases. Teriparatide, an osteoanabolic agent, appears to be the preferred treatment option in OI cases considering its well tolerated adverse events and positive effects on bone mineral density observed in studies. Further longer term studies involving a larger number of patients are needed to confirm and contrast our findings.
\end{abstract}

Key Words: Osteogenesis imperfecta. Teriparatide. Zolendronic acid. Bone mineral density.

Geliş Tarihi: 03.Kasım.2020

Kabul Tarihi: 02.Aralık.2020

Dr. Yasemin AYDOĞAN ÜNSAL

Bursa Uludağ Üniversitesi Tıp Fakültesi,

Endokrinoloji ve Metabolizma Hastalıkları Bilim Dalı,

Bursa.

Tel: 05375775209

E-posta: yaseminunsalay@gmail.com

Yazarların ORCID ID Bilgisi:

Yasemin AYDOĞAN ÜNSAL: 0000-0002-1566-3099

Özen ÖZ GÜL: 0000-0002-1332-4165

Soner CANDER: 0000-0001-6303-7896

Canan ERSOY: 0000-0003-4510-6282

Ensar AYDEMIR: 0000-0001-8519-784X

Oktay ÜNSAL: 0000-0002-3215-8457

Erdinç ERTÜRK: 0000-0003-2399-6608
Osteogenezis imperfekta (OI) anormal tip 1 kollajen üretimi ile karakterize otozomal dominant kalitılan bağ doku bozukluğudur ${ }^{1}$. Kemiklerde artmış kırık riski mevcuttur. Genetik ve klinik olarak heterojen olan bu hastalı̆̆ın insidansı 1/10.000 - 1/20.000 olarak tahmin edilmektedir ${ }^{2}$. Kemik, deri, tendon ve sklera yapısında yer alan tip 1 kollajen, iki alfa 1 ve bir alfa 2 zinciri olmak üzere, 3 zincirden oluşur. Kollajen 1 alfa 1 (COL1A1) geni pro-alfa 1'i kodlar ve 17. kromozomda bulunur. Kollajen 1 alfa 2 (COL1A2) geni ise proalfa 2'yi kodlar ve 7. kromozomda bulunur. Oİ'li olguların \%90'inda tip 1 kollajeni kodlayan genlerde (COL1A1 ve COL1A2) mutasyon saptanmıştır. 
Kemik matriksinin \%90'1 tip 1 kollajenden, \%10'u kollajen olmayan proteinlerden oluşur. Oİ'de görülen tip 1 kollajeni kodlayan genlerdeki mutasyonlar kemik matriksinin özelliklerini değiştirmekte, osteoblast fonksiyonunu ve kemik oluşumunu etkilemektedir. $\mathrm{Bu}$ mekanizmayla Oİ olgularında kemik kalitesinde bozulma olmakta ve kırılgan kemik tablosu ortaya çıkmaktadır $^{3,4}$. Oİ olgularında tip 1 kollajenden zengin dokuların tamamı etkilenebilmektedir ${ }^{5}$. Olgularda kemik ağrıları, kol ve bacaklarda deformiteler, kısa boy, kifoskolyoz, eklem dislokasyonları sıklıkla görülmektedir. Ayrıca, skleranın aşırı incelmesine bağlı olarak alttaki damar tabakasının görünmesi nedeniyle mavi sklera görünümü, osteoskleroz nedeniyle işitme güçlükleri, diş gelişiminde bozukluklar, deride incelme, çeşitli kardiyolojik ve pulmoner patolojiler görülebilmektedir ${ }^{6-8}$.

Osteogenezis imperfekta olgularında mevcut olan mutasyonun şiddetine göre klinik bulgular değişkenlik gösterebilmektedir. Oİ tanısı sıklıkla erken çocukluk döneminde konulsa da erişkin döneminde osteoporoz ve fraktürler nedeniyle tetkik edilirken de tanı konulabilmektedir. OI'nin karakteristik laboratuvar bulgusu yoktur. Alkalen fosfataz (ALP) ve kemik yıkım parametreleri artmış olabilir. Pozitif aile öyküsü olan bireyde klinik bulguların varlığının yanında tip 1 kollajenin ve onu kodlayan genlerin (COL1A1 ve COL1A2) moleküler analizi tanıyı desteklemektedir ${ }^{9}$.

Osteogenezis imperfektada kesin bir tedavi olmamakla birlikte tedavi ile amaçlanan mobiliteyi ve fonksiyonel kapasiteyi arttırmaktır. Fizik tedavi ve rehabilitasyon, kasların kuvvetlendirilmesi ve kemik dayanıklılığının arttırılmasına yöneliktir. Oluşan kırık ve deformitelerin düzeltilmesine yönelik ise intramedüller fiksasyon veya korrektif osteotomiden faydalanılmaktadır. Spinal deformite tedavisi ise skolyozun açısına göre değişkenlik göstermektedir.

Çoğu merkezde hafif Oİ olguları konservatif yaklaşımla takip edilmektedir. Kemik frajilitesini azaltmaya yönelik medikal tedavi seçeneklerinden bisfosfonatlar, orta ve ciddi hastalık formlarında özellikle çocuklarda etkin tedavi seçenekleri arasında yer almaktadır ${ }^{10}$. Bisfosfonatlar, kemik mineralizasyonunu düzenleyen endojen inorganik pirofosfatların analoglarıdir ${ }^{11}$. Osteoklastları inhibe ederek kemik rezorpsiyonunu azaltmaktadırlar $^{12}$. Paz ve arkadaşlarının Oİ tanılı bireylerde yaptığı çalışmada, zoledronik asit (ZA) tedavisi verilen bireylerde femur boynunda kemik mineral yoğunluğunda artış sağladığı gözlenmiştir. Çalışmada olgularda yan etki gelişmemiş ve Oİ ile ilişkili osteoporoz vakalarında ZA'nın etkin ve güvenilir olduğu ifade edilmiștir ${ }^{13}$.

Teriparatid (rekombinant insan paratiroid hormonu), 34 aminoasitten oluşan anabolizan özellikte peptid yapıda hormondur. Seksen dört aminoasit yapısındaki intakt peptidin bütün biyolojik aktivitelerine sahiptir. Kemik oluşumu ve dansitesini, trabeküler yapının sayı ve kalınlığını arttırır. Kemik mikro-mimarisini güçlendirir ve kırık riskini azaltır ${ }^{14,15}$. Teriparatid, doz bağımlı olarak postmenapozal kadınlarda lomber vertebra ve femur boynu kemik mineral yoğunluğunu arttırmakta, vertebra ve vertebra dıșı kırık riskini belirgin şekilde azaltmaktadır ${ }^{16}$. Patofizyolojisinde osteoblastların normal tip 1 kollajen sentezi yapamaması ve sonuç olarak yetersiz kemik yapımı olan Oİ vakalarında, osteoblast diferansiyasyonu, fonksiyonunu ve sürvisini uyarması ve yeni kemik oluşumunu arttırmas1 nedeniyle teriparatid tedavi seçeneği olarak tercih edilebilmektedir. Orwoll ve arkadaşlarının 79 erişkin Oİ olgularında yaptığı randomize plasebo kontrollü çalışmada 18 aylık tedavi sonrasında teriparatid ve plasebo uygulanan 2 grup karşılaştırılmıştır; teriparatid tedavisi alan olgularda, lomber vertebra ve femurda plasebo grubuna göre kemik mineral yoğunluğunda anlamlı artış tespit edilmiştir ${ }^{17}$.

Bu çalışmada kliniğimizde Oİ tanısı konulan, tedavilerinde teriparatid veya ZA kullanılan hastaların retrospektif olarak klinik, laboratuvar parametreleri ve kemik mineral yoğunluklarının değerlendirilmesi ve karşılaştırılması amaçlanmıştır.

\section{Gereç ve Yöntem}

Kliniğimiz tarafından Oİ tanısı ile takipli olan ve takiplerde teriparatid tedavisi uygulanan 4 hasta ile ZA tedavisi alan 5 hasta demografik, klinik, laboratuvar parametreleri ve kemik mineral yoğunlukları retrospektif olarak değerlendirildi. Yaş, cinsiyet verileri değerlendirildi. Fizik muayenede, mavi sklera ve deformite varlığg incelendi. Aile öyküleri sorguland1.

Hastaların tedavi doz ve sıklıkları değerlendirildiğinde, teriparatid tedavisi alan olgulara 20 mikrogram/gün subkütan olarak, zolendronik asit tedavisi alan olgulara ise 6 ayda bir $5 \mathrm{mg}$ dozunda verildiği görüldü.

Çalışmaya dahil edilen tüm hastaların kemik yoğunlukları, Hologic marka dual X ray absorbsiyometre ile ve aynı cihaz ile değerlendirildi. Tüm hastaların lomber ve femur boyun bölgelerinden alınan kemik mineral yoğunlukları, femur boyun ve lomber $\mathrm{T}$ ve $\mathrm{Z}$ skorları kaydedildi.

Çalışmamız Helsinki Deklarasyonu ilkelerine uygun olarak ve Bursa Uludağ Üniversitesi Tıbbi Araştırmalar Etik Kurulu’nun 24 Eylül 2020 tarihli, 2020 - 16/2 nolu kararı sonrası yapılmıştır.

Tanımlayıcı istatistikler nicel veri için medyan (minimum-maksimum), nitel veriler için frekans olarak belirtilmiştir. 


\section{Bulgular}

Teriparatid tedavisi uygulan olguların 2'si erkek 2'si kadın idi. Yaş ortalaması 47 olan olgularda Oİ tanı yaşı ortalaması 35 yıl idi. Osteoporoz etiyolojisi araştırılan vakaların hepsinde diğer osteoporoz nedenleri açısından da değerlendirme yapıldı. Olguların 2'sinde aile öyküsünde çoklu kırık tarifi mevcuttu. İki olguda mavi sklera izlenirken bir olguda ise eşlik eden işitme kaybı tespit edildi. Boy kısalığı da olan iki hastanın fizik muayenesinde skolyoz da saptandı. Çoklu kırık öyküsü olan vakalardan birinde COL1A1 gen mutasyonu bir hastada ise Plastin 3 (PLS3) homozigot mutasyonu saptanarak tanı genetik analizle desteklendi. Bir hastada ise genetik analiz planı mevcuttu (Tablo I). Bu olguların ortalama serum kalsiyum düzeyi 8.8 $\mathrm{mg} / \mathrm{dL}$, vitamin D düzeyi ise $26.6 \mu \mathrm{g} / \mathrm{L}$ idi (Tablo II). İki olguya vitamin D eksikliği, bir olguya ise yetersizliği nedeniyle vitamin $\mathrm{D}$ tedavisi verilmişti.

Tablo I. Hastaların Demografik Özellikler

\begin{tabular}{|c|c|c|c|c|c|c|c|}
\hline Olgular & $\begin{array}{l}\text { Hasta } \\
\text { yaşı } \\
\text { (yıl) }\end{array}$ & $\begin{array}{l}\text { Tanı } \\
\text { yaşı } \\
\text { (yıl) }\end{array}$ & Cinsiyet & $\begin{array}{l}\text { Mutasyon } \\
\text { analizi }\end{array}$ & $\begin{array}{c}\text { Aile } \\
\text { öyküsü }\end{array}$ & $\begin{array}{l}\text { Mavi } \\
\text { sklera }\end{array}$ & $\begin{array}{c}\text { Kirık } \\
\text { sayısı } \\
\text { (n) } \\
\end{array}$ \\
\hline Olgu 1 & 62 & 43 & Kadın & COL1A & Mevcut & Mevcut & $\begin{array}{l}\text { Çok } \\
\text { sayılda }\end{array}$ \\
\hline Olgu 2 & 33 & 28 & Erkek & - & Yok & Yok & $\begin{array}{c}\text { Çok } \\
\text { şyılda }\end{array}$ \\
\hline Olgu 3 & 44 & 34 & Erkek & $\begin{array}{l}\text { PLS3 } \\
\text { homozigot } \\
\text { mutasyonu }\end{array}$ & Mevcut & Mevcut & $\begin{array}{c}\text { Çok } \\
\text { sayıda }\end{array}$ \\
\hline Olgu 4 & 49 & 36 & Kadın & - & Yok & Yok & $\begin{array}{c}\text { Çok } \\
\text { şyılda }\end{array}$ \\
\hline Olgu 5 & 56 & 9 & Kadın & - & Mevcut & Mevcut & $\begin{array}{l}\text { Çok } \\
\text { sayıda }\end{array}$ \\
\hline Olgu 6 & 45 & 43 & Kadın & - & Mevcut & Mevcut & $\begin{array}{l}\text { ÇoK } \\
\text { sayıla }\end{array}$ \\
\hline Olgu 7 & 40 & 39 & Erkek & COL1A1 & Mevcut & Mevcut & $\begin{array}{l}\text { Çok } \\
\text { sayıda }\end{array}$ \\
\hline Olgu 8 & 79 & 77 & Erkek & COL1A1 & Mevcut & Mevcut & $\begin{array}{l}\text { Çok } \\
\text { sayıda }\end{array}$ \\
\hline Olgu 9 & 52 & 37 & Kadın & COL1A1 & Mevcut & Mevcut & $\begin{array}{c}\text { Çok } \\
\text { sayıla } \\
\end{array}$ \\
\hline
\end{tabular}

Olgu 1 - 4 Teriparatid tedavisi; Olgu 5 - 9 zolendronik asit tedavisi alan hastalar

PLS 3: Plastin 3

Tablo II. Teriparatid ve Zolendronik Asit Tedavisi Uygulanan Olguların Laboratuvar Parametreleri

\begin{tabular}{|lccccc|}
\hline Olgular & $\begin{array}{c}\text { Kalsiyum } \\
(\mathbf{m g} / \mathrm{dL})\end{array}$ & $\begin{array}{c}\text { Fosfor } \\
(\mathrm{mg} / \mathrm{dL})\end{array}$ & $\begin{array}{c}\text { Alkalen } \\
\text { fosfataz } \\
(\mathrm{U} / \mathrm{L})\end{array}$ & $\begin{array}{c}\text { Parathormon } \\
(\mathrm{ng} / \mathrm{L})\end{array}$ & $\begin{array}{c}25 \text { hidroksi } \\
\text { vitamin D } \\
(\mu \mathrm{g} / \mathrm{L})\end{array}$ \\
\hline Olgu 1 & 8.9 & 2.6 & 74 & 26.8 & 23.4 \\
Olgu 2 & 8.7 & - & 141 & 40.3 & $<8$ \\
Olgu 3 & 9 & 2.8 & 30 & 54.9 & 48.2 \\
Olgu 4 & 9.6 & 4.2 & 72 & 66.9 & 14.5 \\
Olgu 5 & 9.2 & 3.3 & 89 & 138.7 & 21.9 \\
Olgu 6 & 8.8 & 3.4 & 73 & 126.8 & 25.6 \\
Olgu 7 & 8.5 & 3.3 & - & 75.6 & 27.8 \\
Olgu 8 & 9.1 & 3 & 66 & 76.5 & 40.6 \\
Olgu 9 & 8.7 & 3.5 & - & 138 & 29.5 \\
\hline
\end{tabular}

Olgu 1 - 4 Teriparatid tedavisi; Olgu 5 - 9 zolendronik asit tedavisi alan hastalar
Olguların tamamına osteoporoz nedeniyle öncelikle oral bisfosfonat tedavisi verilmişti. Olguların üçünde alendronat birinde ise risedronat tedavisi kullanılmıştı. Üç hastada bisfosfonat tedavisi altında yeni frajilite kırığı gelişmesi nedeniyle bir hastada ise tedavi sırasında artan kemik ağrıları ve kemik mineral yoğunluğunda azalma kaydedilmesi nedeniyle teriparatid tedavisine geçilmişti.

ZA tedavisi uygulanan hastaların 3'ü kadın 2'si erkekti. Ortalama yaşları 54 ve Oİ tanı yaşı ise 41 olarak değerlendirildi. Vakaların 3'ü aynı ailenin üyesiydi ve genetik analizde COL1A1 mutasyonu saptanmıştı. Hastaların tamamında mavi sklera ve çoklu kırık öyküsü mevcuttu (Tablo I). Laboratuvar parametreleri değerlendirildiğinde ortalama 25 hidroksi vitamin D düzeyi $29.08 \mu \mathrm{g} / \mathrm{L}$ ve ortalama serum kalsiyum düzeyleri $9.14 \mathrm{mg} / \mathrm{dL}$ olarak değerlendirildi (Tablo II). Beş olgunun 2'sine alendronat sodyum ve 1'ine ibandronik asit tedavisi verilmişti. Tedavi altında yeni kırık oluşumu saptanmayan ancak kemik mineral yoğunluğunda azalma tespit edilen hastalara ZA tedavisi uygulanmıştı. İki hastada ise oral tedavi verilmeksizin ZA tedavisi tercih edilmişti.

Teriparatid tedavisi uygulanan 4 olgunun teriparatid tedavisi öncesinde femur boynunda ortalama kemik mineral yoğunluğu $0.575 \mathrm{~g} / \mathrm{cm}$, ortalama T skoru -2.57 ve $Z$ skoru -2 şeklinde saptand. Lomber vertebralarda değerlendirilen ortalama kemik mineral yoğunluğu ise $2.54 \mathrm{~g} / \mathrm{cm}$, T skoru -3 ve Z skoru -3.5 idi.

Olguların ortalama teriparatid kullanım süresi 13.5 ay idi. Bir hastanın takiplere gelememesi nedeniyle teriparatid tedavisi 6 ay uygulanabildi. Teriparatid tedavisi sırasında olgularda yan etki gelişmedi. Olguların hiçbirinde yeni kırık oluşumu saptanmazken tüm hastalarda klinik iyileşme saptandı.

Teriparatid tedavisi alan hastalarda, dual $\mathrm{X}$ ray absorbsiyometre ile lomber ve femur boyun bölgelerinde kaydedilen kemik mineral yoğunluk ölçümleri, $\mathrm{T}$ ve $\mathrm{Z}$ skorları Tablo III ve IV'de özetlenmiştir. Hastaların teriparatid tedavisi ile kemik mineral yoğunluklarının stabil seyrettiği görülmüştür.

ZA tedavisi uygulanan olguların tedavi öncesinde kemik dansitometreleri değerlendirildiğinde femur boynunda ortalama kemik mineral yoğunluğu 0.573 $\mathrm{g} / \mathrm{cm}$, T skor -2.54 ve Z skor -1.94 idi. Olguların kemik mineral yoğunluğu ve DXA skorları Tablo III ve IV'de özetlenmiştir. Olguların tamamında ZA tedavisi ile kemik ağrılarında azalma izlendi. Tedavi sırasında yan etki gelişmedi. Olgularda yeni kırık oluşumu tespit edilmedi. Kemik mineral yoğunlukları değerlendirildiğinde femur boynunda iki hastada kemik mineral yoğunluğunda azalma olduğu görülürken, tüm hastalarda lomber alanda kemik mineral yoğunluğunda artış izlendi. 
Tablo III. Uygulanan Tedavilerin Önce ve Sonrasında Femur Boynu Kemik Dansitometre Değerleri

\begin{tabular}{|c|c|c|c|c|c|c|}
\hline \multirow{2}{*}{ Olgular } & \multicolumn{2}{|c|}{$\begin{array}{c}\text { Femur boynu } \\
\text { KMY }\left(\mathbf{g} / \mathrm{cm}^{2}\right)\end{array}$} & \multicolumn{2}{c|}{$\begin{array}{c}\text { Femur boynu } \\
\text { T skor }\end{array}$} & \multicolumn{2}{c|}{$\begin{array}{c}\text { Femur boynu } \\
\text { Z skor }\end{array}$} \\
\cline { 2 - 7 } & $\begin{array}{c}\text { Tedavi } \\
\text { öncesi }\end{array}$ & Sonrası & $\begin{array}{c}\text { Tedavi } \\
\text { öncesi }\end{array}$ & Sonrası & $\begin{array}{c}\text { Tedavi } \\
\text { öncesi }\end{array}$ & Sonrası \\
\hline Olgu 1 & 0.533 & 0.498 & -2.9 & -3.2 & -1.7 & -1.9 \\
\hline Olgu 2 & 0.655 & - & -2 & - & $-1,8$ & - \\
\hline Olgu 3 & 0.589 & 0.578 & -2.5 & -2.6 & -2 & -2.1 \\
\hline Olgu 4 & 0.524 & 0.511 & -2.9 & -3 & -2.5 & -2.5 \\
\hline Olgu 5 & 0.500 & 0.431 & -3.1 & -3.8 & -3.2 & -2.7 \\
\hline Olgu 6 & 0.608 & 0.644 & -2.2 & -1.8 & -1.8 & -1.4 \\
\hline Olgu 7 & 0.612 & 0.621 & -2.3 & -2.3 & -1.9 & -1.8 \\
\hline Olgu 8 & 0.555 & 0.577 & -2.8 & -2.6 & -1.3 & -1.1 \\
\hline Olgu 9 & 0.590 & 0.565 & -2.3 & -2.6 & -1.5 & -1.7 \\
\hline
\end{tabular}

Olgu 1 - 4 Teriparatid tedavisi; Olgu 5 - 9 zolendronik asit tedavisi alan hastalar

KMY: kemik mineral yoğunluğu

Tablo IV. Uygulanan Tedavilerin Öncesinde ve Sonrasinda Lomber Vertebrada Kemik Dansitometre Parametrelerindeki Değişiklikler

\begin{tabular}{|l|c|c|c|c|c|c|}
\hline \multirow{2}{*}{ Olgular } & \multicolumn{2}{|c|}{$\begin{array}{c}\text { Lomber total } \\
\text { KMY (g/cm²) }\end{array}$} & \multicolumn{2}{c|}{$\begin{array}{c}\text { Lomber total } \\
\text { T skor }\end{array}$} & \multicolumn{2}{c|}{$\begin{array}{c}\text { Lomber total } \\
\text { Z skor }\end{array}$} \\
\cline { 2 - 7 } & $\begin{array}{c}\text { Tedavi } \\
\text { öncesi }\end{array}$ & Sonrası & $\begin{array}{c}\text { Tedavi } \\
\text { öncesi }\end{array}$ & Sonrası & $\begin{array}{c}\text { Tedavi } \\
\text { öncesi }\end{array}$ & Sonrası \\
\hline Olgu 1 & 0.537 & 0.530 & -4.6 & -4.5 & -3.4 & -3.2 \\
\hline Olgu 2 & 0.645 & - & -4.1 & - & -4.1 & - \\
\hline Olgu 3 & 0.541 & 0.548 & -5 & -4.9 & -4.9 & -4.8 \\
\hline Olgu 4 & 0.824 & 0.816 & -2 & -2.1 & -1.6 & -1.5 \\
\hline Olgu 5 & 0.581 & 0.625 & -4.2 & -3.8 & -3.2 & -2.8 \\
\hline Olgu 6 & 0.876 & 0.937 & -1.6 & -1 & -1.2 & -0.6 \\
\hline Olgu 7 & 0.607 & 0.719 & -4.4 & -3.4 & -4.3 & -3.3 \\
\hline Olgu 8 & 0.668 & 0.726 & -3.8 & -3.3 & -2.7 & -2.2 \\
\hline Olgu 9 & 0.574 & 0.610 & -4.3 & -4 & -3.5 & -3.1 \\
\hline
\end{tabular}

Olgu 1 - 4 Teriparatid tedavisi; Olgu 5 - 9 zolendronik asit tedavisi alan hastalar

KMY: Kemik mineral yoğunluğu

\section{Tartışma ve Sonuç}

Osteogenezis imperfekta (Oİ) düşük kemik yoğunluğu nedeniyle kırılgan kemik hastalığı olarak bilinen nadir görülen kalıtsal bağ doku bozukluğudur ${ }^{18}$. Klinik ve genetik olarak oldukça heterojen bir hastalıtır. Oİ olgularının tedavisine endokrin, ortopedik, nörolojik, kardiyolojik problemler de göz önünde bulundurularak, fizyoterapist gerekirse gögüs hastalıkları, göğüs cerrahisi, beslenme desteği ve odyolojik değerlendirme ile bütüncül yaklaşılmalıdır. Tedavi kişiselleștirilmeli; hastalık şiddeti, hasta yaşı ve komorbitideleri de göz önüne alınarak planlanmalıdır. Tedavi semptomların önlenmesi ve kontrol altında tutulması, yeterli mobilitenin sağlanması ve optimal kas gücünün ve kitlesinin saptanmasına yönelik olmalıdır.
Osteogenezis imperfekta olgularında medikal tedavide sıklıkla tercih edilen bisfosfanatların, osteoklastları inaktive edip antirezorptif etki göstererek ağrıda azalmaya neden olduğu, günlük yaşam aktivitelerinde ve kemik mineral yoğunluğunda artış sağladığı gösterilmiştir $^{19}$. Çocuk Oİ olgularında siklik intravenöz pamidronat, zoledronat ve neridronat uygulamalarının etkin olduğu saptanmıştır. Ancak erişkinlerde ve çocuklarda hangi hastalara tedavi verilmesi gerektiği, bisfosfonat seçiminin nasıl yapılacağı, etkin en düşük dozun ve kullanım süresinin belirlenmesi için bisfosfonatların spesifik etkilerini içeren randomize kontrollü çalışmalara ihtiyaç vardır ${ }^{20}$. Chevrel ve arkadaşları 64 Oİ tanılı bireyde plasebo kontrollü alendronat ile yaptığı çalışmada femur ve lomber vertebra kemik mineral yoğunluğunda anlamlı artış saptamışlardır. Aynı çalışmada kırık oranları ile ilgili önemli fark saptanmamıştır $^{21}$. Shapiro ve arkadaşlarının 90 Oİ vakasında yaptığı değerlendirmede ise olgulara intravenöz pamidronat ve oral risedronat ve alendronat tedavisi uygulanmış ve tüm bisfosfanatların lomber vertebrada kemik mineral yoğunluğunu arttırdığı, oral bisfosfanatların ise femurda kemik mineral yoğunluğunu arttırdığı görülmüștür ${ }^{22}$. Kırık oranında azalma ise sadece intravenöz pamidronat tedavisi verilen tip 3 ve 4 Oİ olgularında gözlenmiştir. Çalışmada değerlendirilen olgular, çalışma planlamadan önce bisfosfanat ve teriparatid tedavisini almıştı. Çalışmamızda Teriparatid tedavisi uygulanan 4 olguda bu tedavi öncesinde oral bisfosfanat tedavisi verildiği; ancak tedavi ile 3 hastada yeni kırık oluşumu 1 hastada ise tedavi altında kemik ağrılarında artış tespit edilmesi ve kemik mineral yoğunluğunda azalma saptanması nedeniyle teriparatid tedavisinin tercih edildiği kaydedildi. ZA tedavisi alan grupta ise, 3 hastada oral bisfosfanat ile kemik mineral yoğunluğunda azalma olması nedeniyle parenteral ZA tedavisine geçildiği görüldü.

Aslan ve arkadaşlarının postmenapozal kadınlarda oral ve intravenöz ZA kullanımının DXA ile değerlendirdiği çalışmada postmenopozal osteoporoz tedavisinde oral ve parenteral bifosfonatların etkili olduğu görüldü ${ }^{23}$. Bununla birlikte vertebra ve femur T skorlarında ve femur kemik mineral yoğunluğunda gözlenen düzelme bakımından parenteral bisfosfonatların daha etkili olduğu belirtildi. Olgularımızda da oral bisfosfanat tedavisi verilen 4 hastanın 3'ünde yeni kırık oluşumu olması, 1 hastada ise kemik mineral yoğunluğunda azalma tespit edilmesi nedeniyle teriparatid tedavisine geçildiği görüldü. ZA tedavisi uygulanan 5 olguda ise tedavi ile lomber vertebrada kemik mineral yoğunluğunda artma, $\mathrm{T}$ ve $\mathrm{Z}$ skorlarda olumlu yönde değişiklikler olduğu saptand1.

Bisfosfonatların güçlü antirezorptif özellikleri normal remodeling aktiviteyi inhibe ederek kemiğin yenilenmesi ve tamirini sağlar; ancak kalsifiye kıkırdak oluşumu nedeniyle zayıf kemik iyileşmesi ve kırılganlıkta 


\section{Osteogenezis İmperfektada Teriparatid Tedavisi}

artma olması dikkate alınması gereken hususlar arasındadır. $^{22,24}$. Yapılan çalışmalarda Oİ vakalarında bisfosfanat tedavisinin kemik mineral yoğunluğunu arttırdığı izlenmiş olsa da kemik yapım - yıkım döngüsünü ve kemik yapımını azalttıklarından kemik yapımı ve osteoblastik fonksiyonlarında bozukluk olan bireylerde etkin olmayabilirler ${ }^{23,24}$. Bisfosfonat kullanımın bir diğer dezavantajı ise oral yararlanımları \%1 - 3 arasında olmasına rağmen çok uzun süreler kemik retansiyonları devam eder. Uzun kemik retansiyon süresi ve remodeling olayının sürekliliği nedeniyle gebe kalma olasılığ̀ / isteği olan fertil Oİ olgularında dikkatli kullanılmalıdır ${ }^{25}$.

Rekombinant insan parathormon peptidi olan teriparatid kemik yapımını uyarmakta ve postmenapozal osteoporozda vertebra ve vertebra dışı kırıkları azaltmak$\operatorname{tad}^{26}{ }^{2}$. Oİ vakalarında teriparatid tedavisinin değerlendirildiği Orwoll ve arkadaşlarının yaptığı çalışmada teriparatidin kemik mineral yoğunluğu üzerinde olumlu etkileri olduğu gözlenmiştir ${ }^{17}$. Shidharan ve arkadaşları tarafından Oİ olgularında oral ve intravenöz bisfosfonat, teriparatid ve anti-sklerostin antikor, yüksek doz vitamin $\mathrm{D}$, rekombinant büyüme hormonu tedavisinin değerlendirildiği metaanalizde oral bisfosfonat ve teriparatidin plasebo grubuna kiyasla kemik mineral yoğunluğunda anlamlı artışa yol açtığı gözlenmiştir; ancak kırık riskinde azalma ile ilgili ilişki saptamamışlardır ${ }^{27}$. Teriparatid tedavisi uygulanan olgularımızda yeni frajilite kırığı gözlenmemiş ve olgularımız teriparatid tedavisi ile kemik ağrılarında azalma ve klinik olarak iyileşme tariflemişlerdi. Değerlendirdiğimiz 1 olguda teriparatid tedavisi ile lomber vertebrada kemik mineral yoğunluğunda artış ve 2 vakada lomber vertebra $\mathrm{T}$ skorlarında, 3 vakada ise lomber vertebra $\mathrm{Z}$ skorlarında düzelme saptanmıştı. Vakalara teriparatid uygulanma süresi değerlendirildiğinde yalnızca 2 vakada 18 ay teriparatid tedavisi uygulanabildiği görüldü. Diğer 2 vakada çeşitli nedenlerden dolayı teriparatid tedavisi daha kısa uygulanabildi. Lomber vertebrada kemik mineral yoğunluğunda, $T$ ve $Z$ skorlarında gözlenen artış incelendiğinde 18 ay teriparatid tedavisi uygulanan vakalarda bu artışın daha belirgin olduğu saptandı. Bu durum teriparatid tedavi sürelerinin de etkinlik değerlendirmesinde önem taşıdığını göstermektedir.

Orwoll ve arkadaşlarının yaptığı çalışmada kemik mineral yoğunluğundaki değişiklikler daha çok trabeküler kemik bölgelerinde tespit edilmiştir. Femur boynu ve radial kemik ölçümlerinde tedavi ile belirgin değişiklik saptanmamıştır. Bu durum daha önce osteoporoz nedeniyle teriparatid tedavisi uygulanan bireylerde de benzer olarak tespit edilmiştir ${ }^{17}$. Bizim olgularımızda da olumlu etkiler daha çok lomber vertebralarda görülmüş olup teriparatid tedavisi uygulanan olgularımızın hiçbirinde tedavi sırasında kırık meydana gelmemiştir. Teriparatid uygulanan hastalarımızda daha önce oral bisfosfonat tedavisi ile yeni kırık olu- şumu ve kemik mineral yoğunluklarında azalma olduğu göz önüne alındığında teriparatid tedavisinin tedaviye daha dirençli olgularda kullanıldığı sonucuna varılabilir. Teriparatid kullanımının yan etkileri bulantı, ortostatik hipotansiyon ve bacak kramplarıdır. Hiperkalsemi s1k olmamakla birlikte genellikle hafif, asemptomatik ve geçicidir. Ortostatik hipotansiyon ilk birkaç dozda görülmekte ve pozisyonla düzelmektedir. İlaç allerjileri, ürtiker, baş ağrısı, gastrointestinal semptomlar, farenjit gözlenebilen yan etkilerdir ${ }^{28-30}$. Olgularımızda teriparatid iyi tolere edilmiştir ve herhangi bir yan etki izlenmemiştir.

Çalışmamızdaki kısıtlılıklar, teriparatid ve ZA tedavisi uygulanan olgu sayımızın az olması ve retrospektif analiz yapılmış olmasıdır. Diğer bir kısıtlılık ise ilaç gruplarının etkinliğini sadece DXA ile belirlenen kemik mineral yoğunluğu, $T$ ve $Z$ skorlarıyla değerlendirmiş olmamızdır. Bizim çalışmamızda retrospektif değerlendirilen hasta dosyalarında takipte kullanılan önemli belirteçler olan kemik yıkım belirteçleri ve vitamin D seviyelerinde eksiklikler olduğundan yeterli değerlendirme yapılamamıştır.

Sonuç olarak, osteogenezis imperfekta tanısı alan hastalarda tedavi kararı hastanın özellikleri, daha önce aldığı tedaviler, fraktür gelişimi gibi faktörler göz önüne alınarak bireyselleştirilmelidir. Çalışmamızda klinik olarak daha şiddetli olduğu düşünülen ve oral bisfosfonat tedavisi altında kırık gelişen hastalarda teriparatid tedavisi uygulanmıs ve tedavi süresince ve sonrasında yeni kırık gelișimi saptanmamıștır. Öte yandan oral bisfosfonat ile kemik mineral yoğunluğunda azalma olan ancak kırık olmayan yani klinik olarak daha az şiddetli olduğu düşünülen hastalara ZA verilmiş ve tedavi sonrasında kemik mineral yoğunluğunda artış izlenmiştir. Çalışmamızda hem teriparatid tedavisinin hem de intravenöz ZA tedavisinin Oİ hastalarında etkin tedaviler olduğu saptanmıştır.

Etik Kurul Onay Bilgisi:

Onaylayan Kurul: Uludağ Üniversitesi Tıp Fakültesi Klinik

Araştırmalar Etik Kurulu.

Onay Tarihi: 16.09 .2020

Karar No: 2020-16/2

\section{Kaynaklar}

1. Glorieux FH. Osteogenesis imperfecta. Best Pract Res Clin Rheumatol 2008; 22 (1): 85 - 100

2. Marini JC, Forlino A, Bachinger HP, Bishop NJ, Byers PH, Paepe A, Fassier F, Fratzl-Zelman N, Kozloff KM, Krakow D, et al. Osteogenesis imperfecta. Nature Reviews: Disease Primers 2017; 3: 17052.

3. Folkestad L, et al. Bone geometry, density, and microarchitecture in the distal radius and tibia in adults with osteogenesis imperfecta type I assessed by high-resolution pQCT. J Bone Miner Res. 2012; 27 (6): 1405 - 1412.

4. Gatti D, et al. The volumetric bone density and cortical thickness in adult patients affected by osteogenesis imperfecta. J Clin Densitom. 2003; 6 (2): 173 - 177. 
5. Marini JC. Osteogenesis imperfecta: comprehensive management. Adv Pediatr 1988; 35: 391 - 426.

6. Glosten B. Osteogenesis imperfecta. In: Gambling, DR, Douglas MJ, editors. Obstetric anesthesia and uncommon disorders. Philadelphia, WB Saunders; 1998: 213 -8.

7. Burnei G, Vlad C, Georgescu I, Gavriliu TS, Dan D. Osteogenesis imperfecta: diagnosis and treatment. J Am Acad Orthop Surg 2008;16 (6): 356 - 66.

8. Michaell A.Huber, DDS.Osteogenesis imperfecta.Oral Radiol Endod 2007; 103: 314 - 20

9. Hekimsoy Z., Osteogenesis İmperfekta. Turkiye Klinikleri J Endocrin. 2009; 4 (3): 85 - 91.

10. Cheung MS, Glorieux FH. Osteogenesis imperfecta: update on presentation and management. Rev Endocr Metab Disord. 2008; 9: $153-160$.

11. Font RF, Garcia ML, Martinez JMO. Osteochemonecrosis of the Jaws due to Bisphosphonate treatments: Update. Med Oral Patol Oral Cir Bucal 2008; 13: 318 - 24.

12. Sparidans RW, Twiss IM, Talbot S. Bisphosphonates in bone diseases. Pharm World Sci 1998; 20: 206 - 13.

13. Pavón de Paz I, Iglesias Bolaños P, Durán Martínez M, Olivar Roldán J, Guijarro De Armas G, Parra García JI. Efectos del tratamiento con ácido zoledrónico en pacientes adultos con osteogénesis imperfecta [Effects of zoledronic acid in adults with osteogenesis imperfecta]. Endocrinol Nutr. 2010 Jun - Jul; 57 (6): 245 - 50

14. Forteo R. Teriparatide [rDNA origin] injection. Kobe, Japan: Eli Lilly Japan K.K; 2014.

15. Hodsman AB, Bauer DC, Dempster DW, et al. Parathyroid hormone and teriparatide for the treatment of osteoporosis: a review of the evidence and suggested guidelines for its use.Endocr Rev. 2005; 26: 688 - 703.

16. Dobnig H, Sipos A, Jiang Y, et al. Early changes in biochemical markers of bone formation correlate with improvements in bone structure during teriparatide therapy. J Clin Endocrinol Metab 2005; 90: 3970.

17. Orwoll ES, Shapiro J, Veith S, Wang Y, Lapidus J, Vanek C, Reeder JL, Keaveny TM, Lee DC, Mullins MA, Nagamani SC \& Lee B. Evaluation of teriparatide treatment in adults with osteogenesis imperfecta. Journal of Clinical Investigation 2014; 124: 491 - 498.

18. Martin E, Shapiro JR. Osteogenesis Imperfecta: epidemiology and pathophysiology. Curr Osteoporos Rep 2007;5: 91 - 97.
19. Balkefors V, Mattsson E, Pernow Y, Sääf M. Functioning and quality of life in adults with mild-to-moderate osteogenesis imperfecta. Physiother Res Int 2013; 18: 203 - 211.

20. Rohrbach M, Giunta C. Recessive osteogenesis imperfecta: clinical, radiological, and molecular findings. Am J Med Genet C Semin Med Genet 2012;160: 175 - 189.

21. Chevrel G, Schott AM, Fontanges E, Charrin JE, Lina-Granade G, Duboeuf F, Garnero P, Arlot M, Raynal C, Pierre J, Meunier PJ. Effects of oral alendronate on BMD in adult patients with osteogenesis imperfecta: a 3-year randomized placebocontrolled trial. J Bone Miner Res. 2006;21(2): 300 - 306.

22. Shapiro JR, Thompson CB, Wu Y, Nunes M, Gillen C. Bone mineral density and fracture rate in response to intravenous and oral bisphosphonates in adult osteogenesis imperfecta. Calcif Tissue Int.2010; 87 (2): 120 - 129.

23. Aslan A, Gülcü A, Özmeriç A. Yaşlı Postmenapozal Osteoporozlu Hastalarda Tedavi Sonuçlarımız: Oral ve Parenteral Bifosfonatların Karşılaştırılması. Turk J Osteoporos 2018; 24: 53 -8 .

24. Land C, Rauch F, Glorieux FH. Cyclical intravenous pamidronate treatment affects metaphyseal modeling in growing patients with osteogenesis imperfecta. J Bone Miner Res 2006; 21: 374 - 379.

25. Lin JH. Bisphosphonates: a review og their pharmacokinetic properties. Bone 1996; 18: 75 - 85.

26. Neer RM, Arnaud CD, Zanchetta JR, et al. Effect of parathyroid hormone (1 - 34) on fractures and bone mineral density in postmenopausal women with osteoporosis. N Engl J Med 2001; 344: 1434.

27. Sridharan K, Sivaramakrishnan G. Interventions for Improving Bone Mineral Density and Reducing Fracture Risk in Osteogenesis Imperfecta: A Mixed Treatment Comparison Network Meta-analysis of Randomized Controlled Clinical Trials. Curr Clin Pharmacol. 2018; 13 (3): 190 - 198.

28. Vahle JL, Long GG, Sandusky G, Westmore M, Ma YL, Sato $\mathrm{M}$. Bone neoplasms in F344 rats given teriparatide [rhPTH(1 $34)]$ are dependent on duration of treatment and dose. Toxicol Pathol. 2004; 32: 426 - 438.

29. Harper KD, Krege JH, Marcus R, Mitlak BH. Osteosarcoma and teriparatide? J Bone Miner Res. 2007; 22: 334.

30. Subbiah V, Madsen VS, Raymond AK, Benjamin RS, Ludwig JA. Of mice and men: divergent risks of teriparatide-induced osteosarcoma. Osteoporos Int. 2010; 21: 1041 - 1045. 